\title{
Network Experiences from a Cross-Sector Biosafety Level-3 Laboratory Collaboration: A Swedish Forum for Biopreparedness Diagnostics
}

\author{
Johanna Thelaus, Anna Lindberg, Susanne Thisted Lambertz, Mona Byström, Mats Forsman, \\ Hans Lindmark, Rickard Knutsson, Viveca Båverud, Andreas Bråve, Pontus Jureen, Annelie Lundin Zumpe, \\ and Öjar Melefors
}

The Swedish Forum for Biopreparedness Diagnostics (FBD) is a network that fosters collaboration among the 4 agencies with responsibility for the laboratory diagnostics of high-consequence pathogens, covering animal health and feed safety, food safety, public health and biodefense, and security. The aim of the network is to strengthen capabilities and capacities for diagnostics at the national biosafety level-3 (BSL-3) laboratories to improve Sweden's biopreparedness, in line with recommendations from the EU and WHO. Since forming in 2007, the FBD network has contributed to the harmonization of diagnostic methods, equipment, quality assurance protocols, and biosafety practices among the national BSL-3 laboratories. Lessons learned from the network include: (1) conducting joint projects with activities such as method development and validation, ring trials, exercises, and audits has helped to build trust and improve communication among participating agencies; (2) rotating the presidency of the network steering committee has fostered trust and commitment from all agencies involved; and (3) planning for the implementation of project outcomes is important to maintain gained competencies in the agencies over time. Contacts have now been established with national agencies of the other Nordic countries, with an aim to expanding the collaboration, broadening the network, finding synergies in new areas, strengthening the ability to share resources, and consolidating long-term financing in the context of harmonized European biopreparedness.

Keywords: Biopreparedness, Diagnostics, BSL-3 laboratory, High-consequence pathogens, Quality assurance, Network

Johanna Thelaus, $\mathrm{PhD}$, is a Researcher; Mona Byström, BSc, is a Senior Scientist; and Mats Forsman, PhD, is Research Director; all in the Division of CBRN Defence and Security, Swedish Defence Research Agency (FOI), Umeå, Sweden. Dr. Forsman is also an Associate Professor, Department of Molecular Biology, Umeå University. Anna Lindberg, PhD, is a Researcher, Department of Microbiology; Rickard Knutsson, PhD, is Director of the Security Department; and Viveca Bàverud, DVM, PhD, is an Associate Professor, Head of Office of Quality; all at the National Veterinary Institute (SVA), Uppsala, Sweden. Susanne Thisted Lambertz, $\mathrm{PhD}$, is a Microbiologist; Hans Lindmark, PhD, is Head of the Biology Department; and Annelie Lundin Zumpe, PhD, is an Advisor, Advice and Emergency Preparedness Department; all at the National Food Agency, Uppsala, Sweden. Dr. Lambertz is also an Associate Professor, Department of Biomedical and Veterinary Public Health, Swedish University of Agricultural Sciences, Uppsala, Sweden. Andreas Bråve, PhD, is Head of the Unit for the High Containment Laboratories; Pontus Jureen, PhD, is an Analyst, Unit for Preparedness Diagnostics; and Öjar Melefors, PhD, is an Analyst, Unit for the High Containment Laboratories; all are at the Public Health Agency of Sweden, Solna, Sweden. Dr. Melefors is also an Associate Professor, Karolinska Institutet, Solna, Sweden.

(C) Johanna Thelaus et al., 2017; Published by Mary Ann Liebert, Inc. This Open Access article is distributed under the terms of the Creative Commons Attribution Noncommercial License (http://creativecommons.org/licenses/by-nc/4.0/) which permits any noncommercial use, distribution, and reproduction in any medium, provided the original author(s) and the source are credited. 
$I^{\mathrm{N}}$ $\mathrm{N}$ RECENT YEARS, there have been numerous cases of emerging pathogens spreading internationally. This increase in such cases is likely to be a consequence of human actions, including the effects of globalization, increased human mobility, and an expanded international trade in animal and food products. ${ }^{1-4}$ Many of these pathogens are classified as "high-consequence pathogens" because they pose a direct threat to both human and animal health. High-consequence pathogens have the potential to cause disruptions in society from actual outbreaks or merely through the potential to create widespread fear in society. There is also an implicit risk that such high-consequence pathogens could be used for antagonistic purposes, such as in bioterrorist attacks. ${ }^{5}$ Although there have, to date, been only a few instances of bioterrorism, many subversive groups have expressed bioterrorist ambitions, creating an urgent need for national preparedness in the early detection and containment of biological security threats. ${ }^{6,7}$

Preventing and handling natural, accidental, or deliberate outbreaks of high-consequence pathogens requires preparedness across many institutions and parts of the society, including health care, agriculture, food production, law enforcement, biodefense, border control, and the transport sector. ${ }^{8}$ Joint biopreparedness calls for cross-sector cooperation at a national level, but at the same time needs to be coordinated with regional and local operations within the various sectors. ${ }^{9}$ There are several existing examples of national cross-sector laboratory response networks-that is, networks of laboratories that can identify high-consequence pathogens and respond to different biological threats in a country. ${ }^{9-13}$

Experience shows that organizing and coordinating networks can be challenging in those countries where there is limited cooperation between different sectors ${ }^{14}$-for example, where each sector relates to different ministries or is governed by separate legal frameworks. Within the European Union (EU), the European Commission has launched a green paper on biopreparedness, ${ }^{15,16}$ an EU CBRN action plan, ${ }^{17}$ and EU legislation concerning serious cross-border threats to health. ${ }^{18}$ This EU legislation complements the World Health Organization's (WHO) International Health Regulations (IHR) agreement on crossborder cooperation to combat certain contagious human diseases. ${ }^{19}$ To comply with these regulations, several European laboratory networks have been established. ${ }^{20,21}$

In Sweden the national agencies for public health, animal health and feed safety, food safety, and biodefense and security each has its own biosafety level-3 (BSL-3) laboratories, to which samples are sent for analysis from around the country (Figure 1, Table 1). The Swedish system for crisis management relies on 3 fundamental principles: (1) crises should be managed by the same authorities that manage the relevant activities in normal times; (2) crises should be managed primarily at the local level; and (3) crises should be handled using normal practices. ${ }^{22,23}$ Thus, during a crisis, each sector is responsible only for its own area of expertise, and most crises are managed by the municipalities responsible at a local level. Crises are managed at

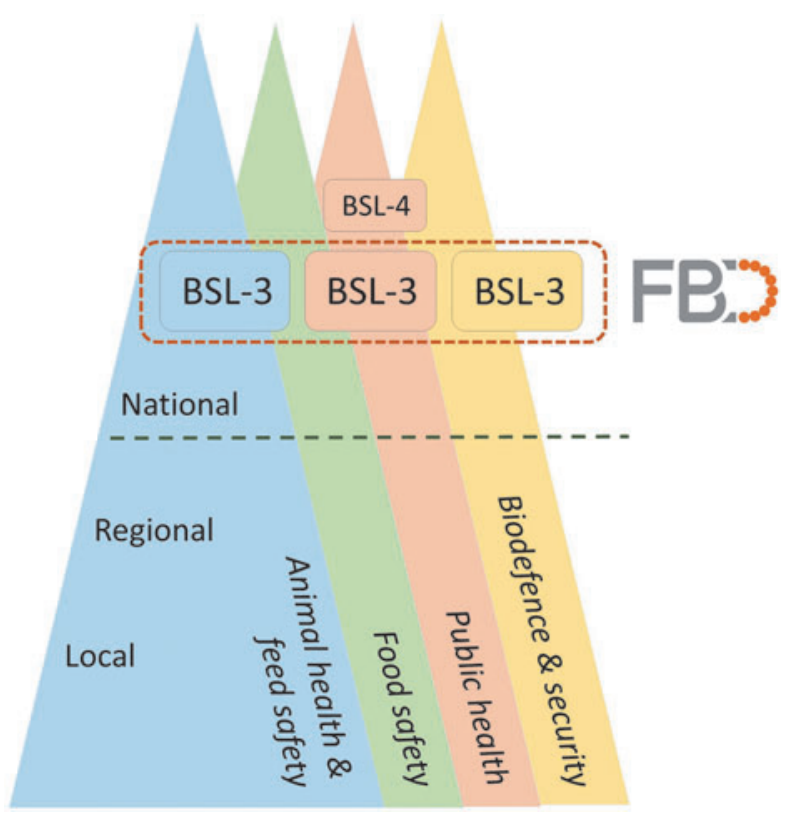

Figure 1. Swedish system for crisis management: the sector. The orange dashed line represents the Swedish Forum for Biopreparedness Diagnostics (FBD) cross-sector cooperation among the 4 national agencies on diagnostics of high-consequence pathogens at the national BSL-3 laboratories.

the national level only if an event spans a wider geographical region (eg, if it affects 2 or more counties), or if the local municipalities require assistance from other regions or from national resources due to workload, or if the presence of microorganisms is suspected requiring expertise found only in the national BSL-3 and -4 laboratories (Figure 1). Maintaining and improving the diagnostics for those rare pathogens that require analysis by BSL-3 and -4 laboratories is resourceintensive. ${ }^{24}$ Moreover, in many cases there are no commercial or standardized methods for analyzing such agents. Usually inhouse solutions are developed, and the total number of staff working in this field is limited. ${ }^{25}$ A joint effort by laboratory personnel from across the different sectors would increase the critical mass of expertise and improve Sweden's biopreparedness against high-consequence pathogens.

\section{National Laboratory Network FOR BSL-3 Diagnostics}

In 2003 the Swedish National Board of Health and Welfare started an exercise to map microbiology laboratories and regional clinical laboratories across Sweden, looking at their capacity and levels of coordination from the perspective of biopreparedness. Among other things, this investigation recommended that the capacity of and coordination between the various microbiology laboratories should be strengthened, in order to ensure a diagnostic service that is sustainable and effective in the event of any crisis generating a large sample load. ${ }^{26}$ 
Table 1. Description of the network's member agencies

\begin{tabular}{lllll}
\hline & \multicolumn{1}{c}{$\begin{array}{c}\text { National Veterinary } \\
\text { Institute (SVA) }\end{array}$} & \multicolumn{1}{c}{$\begin{array}{c}\text { National Food } \\
\text { Agency (NFA) }\end{array}$} & $\begin{array}{c}\text { Public Health Agency } \\
\text { of Sweden (PHAS) }\end{array}$ & $\begin{array}{c}\text { Swedish Defence } \\
\text { Research Agency (FOI) }\end{array}$ \\
\hline Sector & Animal health and feed safety & Food safety & Public health & Biodefence and security \\
Facilities & BSL-3 & BSL-3 & BSL-3, BSL-4 & BSL-3 \\
Location & Uppsala & Uppsala & Solna & Umeå \\
Ministry & Enterprise and innovation & Enterprise and innovation & Health and social affairs & Defence \\
\hline
\end{tabular}

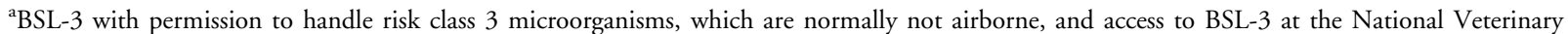
Institute.

In addition, in 2004 the Swedish Laboratory for Food Safety and Biopreparedness was established. This collaboration between the National Veterinary Institute and the National Food Agency initially focused on biopreparedness and the deliberate spread of pathogens in the food chain. ${ }^{27}$ These 2 national initiatives, together with the influence of other international and EU activities, led the 4 agencies with responsibility for dealing with high-consequence pathogens to establish the Swedish Forum for Biopreparedness Diagnostics (FBD) in 2007 (Table 1, Figure 2). The aim of FBD was to strengthen capabilities and capacities for diagnostics at the national BSL-3 laboratories through harmonization. In the event of a crisis, network activation relies on a request of assistance from any of the network agencies. Upon activation, samples may be shipped to the assisting agencies that will assist with the diagnostics.

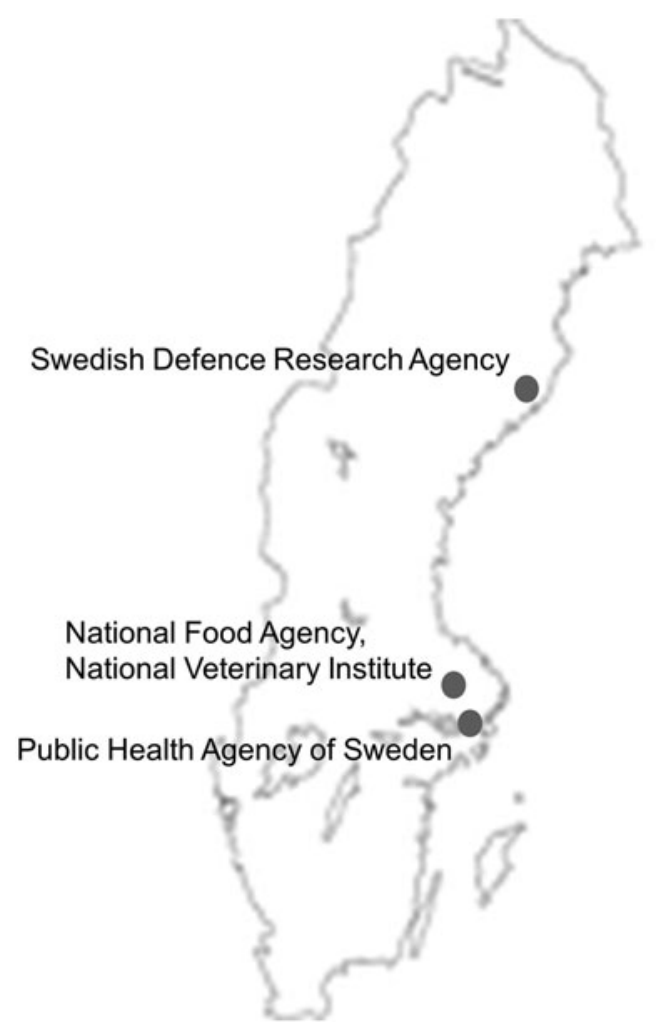

Figure 2. Locations of the 4 Swedish Network Agencies
Three of the agencies- the National Veterinary Institute, the National Food Agency, and the Public Health Agency of Sweden - have designated responsibility for expertise and diagnostics of high-consequence pathogens (risk class $3 \mathrm{mi}-$ croorganisms) within their sectors. In addition, the Swedish Defence Research Agency is the national authority for research and expertise in defense and security (Table 1, Figure 2). Collaboration agreements were signed by the 4 agencies in 2008 and renewed in 2014. The network project has been funded by the Swedish Civil Contingencies Agency for 4 consecutive periods and has now been running since 2007. The Swedish Civil Contingencies Agency is a national agency with the mission to improve the management of crises in society. This is often carried out by granting temporary project funding to stakeholders who are involved in handling crises at the national and local or regional levels.

\section{Network Organization}

The FBD network is coordinated by a steering committee that consists of 2 representatives from each of the 4 agencies, and the presidency of the committee is rotating. A number of parallel projects, in which all agencies are represented by at least 1 person, catalyzes cooperation. To assure effective work, a set of network tools was developed. This included a course in project management for all participants, an FBD quality assurance (QA) manual, and a protected Wikimedia work platform (Figure 3). A summary of joint projects, each lasting between 1 and 3 years, is listed in Table 2. Each project has a budget that pays for salaries (typically 10\% of full time for each person involved), consumables, equipment, and travel. Common interests among the agencies define the scope of the projects. Any results and products generated in a project are jointly owned by all 4 agencies.

Besides working on the joint projects, all members of the network meet approximately 3 times a year for a shared workshop, including progress reports and seminars. The network has, so far, involved around 80 people in total, with roughly 30 participants each year. At the end of each project, a report is printed and made available as a PDF on the web page of the Swedish Civil Contingencies Agency, with a summary in English. ${ }^{28}$ 


\section{Agencies}

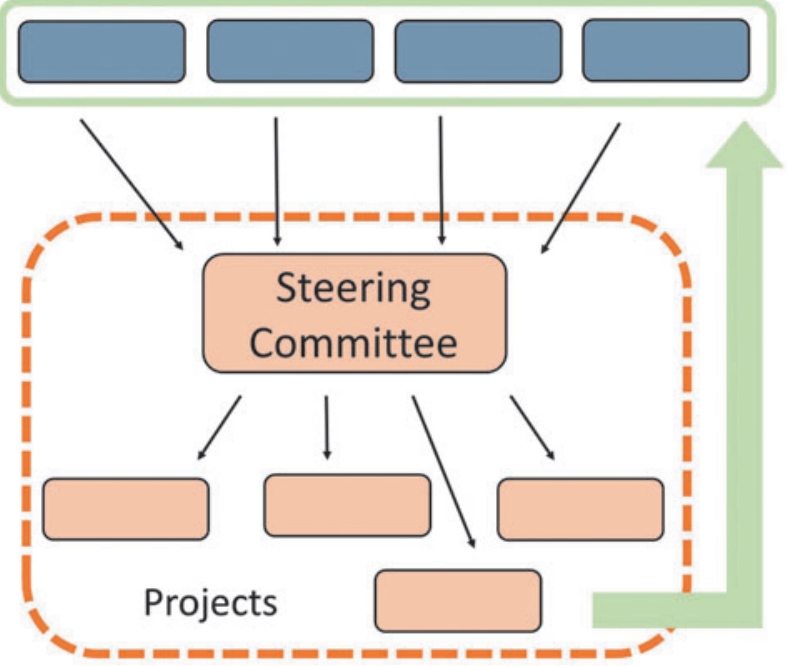

\section{Outcome}

\section{Cooperation}

Ring trials, Exercises and Audits

Harmonization

Diagnostic methods, Laboratory

equipment, QA and Biosafety practices

Nordic collaboration

Reports

\section{Tools}

\section{Collaboration agreement \\ Joint projects \\ Project management education \\ FBD QA manual \\ Workshops \\ Wikimedia}

Figure 3. Organization of the Swedish Forum for Biopreparedness Diagnostics (FBD) network. Joint projects (orange boxes) are identified by the steering committee based on a shared interest among the network agencies (blue boxes). Agencies assign participants to each of the projects, which are run according to the FBD quality assurance manual and with the aid of the other network tools.

\section{LESSONS LEARNED AND DiscusSION}

\section{Harmonization of Laboratories}

Crisis management in Sweden is based on the premise that procedures will be performed as normal; this also includes sample flow upon suspicion of high-consequence pathogens. Within each sector, local and regional actors handle samples and communicate with national resources and BSL-3 laboratories. Given the system, there was an obvious need to develop means for cross-sectoral cooperation between national laboratories in order to improve the country's biopreparedness against high-consequence pathogens. Since its formation in 2007, the FBD network has contributed to the harmonization of diagnostic methods, equipment, QA protocols, and biosafety practices among the national BSL-3 laboratories. It has done this mainly through carrying out joint projects, which have included activities such as ring trials (analysis of spiked samples for detection of highconsequence pathogens), exercises, and audits.

Table 2. Summary of Joint Project Activities in FBD, 2007-16, on diagnostics of high-consequence pathogens at the national BSL-3 laboratories

\begin{tabular}{|c|c|}
\hline Theme & Projects \\
\hline \multirow[t]{3}{*}{ Diagnostic methods } & Gap-analysis to identify the need for method development \\
\hline & Development and validation of molecular diagnostics \\
\hline & Harmonization of methods for bacterial cultivation, including complex matrices: selective culture and enrichment \\
\hline \multirow[t]{3}{*}{ Equipment } & $\begin{array}{l}\text { Ring trials for diagnostics (analysis of spiked live and inactivated samples for detection of } \\
\text { high-consequence pathogens) }\end{array}$ \\
\hline & Dead-end ultrafiltration for diagnostics of high-consequence pathogens in water \\
\hline & Evaluation of DNA extraction robot in BSL-3 biosafety cabinets using various matrices \\
\hline \multirow[t]{3}{*}{ Quality assurance } & Development of a FBD QA manual \\
\hline & Exchange of DNA reference material (strain panels and process controls) \\
\hline & Joint validation of existing PCR assays \\
\hline \multirow[t]{2}{*}{ Biosafety } & $\begin{array}{l}\text { Exercises: interagency transport routines and diagnostics; evaluation of interagency communication during an } \\
\text { infectious disease outbreak; a test of interagency harmonization: collaboration, logistics, and diagnostics }\end{array}$ \\
\hline & Interagency audits on QA of diagnostics and biosafety practices: ISO 17025:2005 and CWA 15793 \\
\hline \multirow{2}{*}{$\begin{array}{l}\text { Nordic collaboration } \\
\text { and dissemination } \\
\text { of FBD output }\end{array}$} & $\begin{array}{l}\text { Initiation of intersectoral collaboration among the Nordic countries in the area of diagnostics at national } \\
\text { BSL-3 laboratories }\end{array}$ \\
\hline & Spreading knowledge about the FBD network to actors working in the field of biopreparedness in Sweden \\
\hline
\end{tabular}

$\mathrm{FBD}=$ Swedish Forum for Biopreparedness Diagnostics; $\mathrm{BSL}=$ biosafety level; DNA=Deoxyribonucleic acid; $\mathrm{QA}=$ quality assurance; $\mathrm{ISO}=$ International Organization for Standardization; CWA=European Centre for Standardization (CEN) Workshop Agreement. 
A 2015 interview-based evaluation of the network, carried out by the Swedish Civil Contingencies Agency, concluded that the 4 partners see their work in FBD as having been democratic, transparent, and equal. ${ }^{29}$ As the Swedish national BSL-3 laboratories work under different ministries, there is no central command structure to which all laboratories are connected, in contrast to, for example, the American Laboratory Response Network, which is overseen by a program leader. ${ }^{30}$

To overcome the inevitable challenges of steering crosssector collaboration, a formal agreement between directors general of the 4 agencies consolidates the FBD network. In addition, the network has a steering committee, which consists of members who have authority to influence the work in each agency and which is responsible for coordinating the network and ensuring a balance in the type of projects run. Having a rotating presidency has fostered trust and commitment from all agencies involved. To date, the FBD network's activities have focused primarily on highconsequence bacteria, and only a few projects have involved emerging viruses. This may be avoided since the original criteria that method development should be relevant for all sectors has been abandoned. An inherent challenge of biopreparedness diagnostics is to gather expertise covering all groups of high-consequence pathogens (ie, bacteria, viruses, RNA viruses, and toxins). Experts covering more than one of these pathogen groups are rare or even nonexistent. Therefore, a systematic turnover of steering group members also helps to assure a diversity of projects and to avoid a bias toward the expertise of particular persons or agencies.

The joint projects and regular meetings have generally created a positive and understanding attitude among the network agencies. Many informal horizontal links have been created, and this has expanded the communication between agencies at all levels. Earlier experience pinpoints mutual trust between partners as a cornerstone for a successful network. ${ }^{31}$ We believe that the key factors in building trust among FBD network members have been joint work on the part of laboratory personnel, significant contribution by each of the participating agencies, and common ownership of results. On a couple of occasions, samples have been sent between the agencies, for example, when there have been problems with equipment or when results have needed to be confirmed, in a manner that would not have been possible before the establishment of the FBD network. One example occurred in 2009 during the first anthrax outbreak in a Swedish beef cattle herd in 27 years. The BSL-3 laboratory at the National Veterinary Institute was responsible for analyzing the samples (mainly blood and animal tissue), the Public Health Agency of Sweden assisted with the confirmation of the first results, and the Swedish Defence Research Agency helped by analyzing the soil samples collected at the site. ${ }^{32}$

The exercises, ring trials, and audits carried out at the network members' various laboratories have shed light on some areas of inconsistency regarding how practices are handled and how Swedish biopreparedness could be improved. They have highlighted, for example, disparities in methods, diagnostic equipment, QA management systems, the transport and delivery of samples, and inter-agency communication and data sharing (Table 2). The challenge of transporting and delivering samples containing class 3 microorganisms is well described by Mèrens et al. ${ }^{13}$ For example, sending samples and metadata requires a system that ensures confidentiality in the laboratory receiving it. In principle, rather than transporting samples to a different laboratory in the network, an alternative would be to exchange staff, as the network members' staff are now familiar with the methods and practices used in the other laboratories.

\section{Diagnostic Methods and Equipment}

Harmonized, quality-assured, up-to-date diagnostic methods have been a key factor in enabling cooperation in the network. The initial idea of having more or less identical methods in all 4 laboratories turned out to be unrealistic, as the different agencies are responsible for different sample types-for example, tissue (human and animal), food, feed, drinking water, and environmental samples. A joint gapanalysis identified the need to improve and share existing methods and in some cases to develop new methods (Table 2). So far, the focus has been on real-time PCR analyses and cultivation methods of the high-consequence pathogens Bacillus anthracis, Brucella spp., Burkholderia mallei, Burkholderia pseudomallei, Coxiella burnetii, Francisella tularensis, Yersinia pestis, and Hanta virus. Two examples of methods that have been developed are the real-time PCR assays for Brucella, later used in a brucellosis outbreak in a Swedish kennel in 2013, ${ }^{33}$ and the real-time PCR for detection of Puumala virus, which has been implemented at clinical hospital laboratories in northern Sweden as a complement to current serological assays. ${ }^{34}$ Furthermore, a thorough evaluation of a DNA extraction robot in biosafety cabinets, including the validation of the extraction process using a broad range of sample types (matrixes), resulted in the equipment's being implemented at all 4 agencies. A method of dead-end ultrafiltration ${ }^{35}$ for detection of highconsequence pathogens in larger volume water also led all 4 agencies to purchase the same equipment.

\section{Quality Assurance and Biosafety Practice}

Previous experiences of laboratory networks have reported on the importance of quality assurance management programs, including reference material and well-designed validation parameters as a basis for inter-agency cooperation. ${ }^{13,24,36-38}$ As the Swedish national BSL-3 laboratories are each governed by their own QA systems and diagnostic methods, it has been important to define how the FBD activities relate to existing ways of doing things. The FBD QA manual has gradually been revised and now covers network organization, project management, implementation planning, 
communicating project results, recommendations on quality assurance of diagnostics at BSL-3 laboratories, and protocols for the validation of diagnostic PCR methods. Thus, the FBD QA manual can be regarded as complementary to each agency's existing management systems.

There is an obvious risk that if the outcomes of network projects are not implemented in members' everyday work, they may be forgotten. To evaluate the implementation of project outcomes, questionnaire interviews were performed at each agency with representatives from the diagnostic laboratories, team leaders, and participants from previous FBD projects. The inventory of the network project outcomes inspired a revision of the FBD QA manual to include a plan for implementation. This means that implementation must be considered right from the start of a new project. Some key factors for successful implementation have been identified:

- A new diagnostic method or new equipment must harmonize with the already existing methods or equipment in each agency;

- The method or equipment is needed by all agencies;

- Adequate validation is performed in the project so that further implementation can be carried out without need for additional work.

Once a new method has been implemented, it is still a challenge for each agency to maintain the relevant competence over time for those methods that are infrequently used, especially in slimmed down organizations. Many high-consequence pathogens are rarely, or have never been, encountered in real-life situations, meaning that the capacity to carry out the relevant methods is not tested on a regular basis. External test panels for such pathogens are generally not commercially available, but capability testing has been made possible in the FBD network projects through in-house ring trials that are performed annually in the network. The ring trials include both live and inactivated samples that are prepared by one FBD arranging laboratory and sent to the other participating agencies. To facilitate validation of the ring trials as well as new and existing diagnostic methods in the network, DNA reference material (ie, strain panels for positive controls and a common internal process control, Phocine Herpes Virions) have been generated and shared among the agencies. As part of one of the FBD projects, interagency audits were performed on quality assurance of diagnostic methods and biosafety at the BSL-3 laboratories, using relevant parts of the ISO 17025 and CWA 15793: Laboratory Biorisk Management. ${ }^{39,40}$ These audits led to improved practical solutions and facilitated the harmonization of good practice between the laboratories.

\section{Dissemination of FBD Outputs}

In another FBD project, the outcomes of network activities were disseminated to other actors working in the field of biopreparedness. Key players with a biopreparedness perspective in Sweden's crisis management system were identified, including county veterinarians, veterinarians in clinical practice, food inspectors at the local level, and relevant personnel in the healthcare sector. Information seminars have been presented at meetings where these groups of professionals gather. Information has also been made available on the relevant authorities' websites, and a leaflet has been produced and distributed.

With a view to initiating a Nordic network for cross-sector collaboration, one FBD project established contact with the corresponding agencies in the other Nordic countries (Denmark, Finland, Iceland, and Norway). Following a joint workshop, the Nordic Biopreparedness Forum was formed in 2015 and is now governed by a committee made up of representatives from each country. A workshop will be organized at least annually, hosted by each country in turn. This will be an important opportunity to uphold and widen the contacts between people in this field, to share knowledge and experience from outbreaks, and to discuss how to improve current methods and strategies for quality assurance. In addition, a bilateral collaboration between Sweden and Norway has resulted in joint ring trials for analysis of spiked samples for detecting high-consequence bacteria. Future network activities could include increased exchange of biological reference materials and strains and expansion of ring trials and proficiency tests.

An intrinsic weakness of the current system of crosssector collaboration is that it is not underpinned by longterm, ongoing financing. Internationalization may broaden the network of national BSL-3 laboratories to find synergies in new areas, strengthen the ability to pool and share resources throughout Europe, and consolidate a longer-term financing regime in the context of harmonized European biopreparedness.

In a previous study, based on experiences gained during 46 years of collaborative work, performed across diverse laboratory cultures, the value of networks has been summarized as having achieved enhanced productivity and trust-greater than any single laboratory could achieve. ${ }^{41}$ Global health security issues will continue to challenge collaboration between sectors, laboratory activities, and technologies in the coming years. ${ }^{42}$ We believe that collaboration among laboratories will be central when it comes to adapting to the rapid technical development that is now ongoing in microbiology laboratories. ${ }^{43,44}$ The cross-sectoral FBD network not only adopts to the One Health concept; ${ }^{45}$ it also leads to improved coordination and harmonization between laboratories that undoubtedly will save resources ${ }^{46,47}$ and strengthen national biopreparedness.

\section{ACKNOWLeDgments}

The authors thank all the present and previous staff and members of the FBD network and Mr. Curt Frodlund at 
Utvecklingsprojekt $\mathrm{AB}$ for his inputs on project management. Projects in FBD have principally been funded through grants from the Swedish Civil Contingencies Agency, 2:4 Krisberedskap. The Nordic workshop in 2016 was funded by the Nordic Working Group for Microbiology and Animal Health and Welfare (NMDD). The views expressed here are those of the authors and do not necessarily represent the position of the Swedish Civil Contingencies Agency.

\section{REFERENCES}

1. Grunow R, Klee SR, Beyer W, et al. Anthrax among heroin users in Europe possibly caused by same bacillus anthracis strain since 2000. Euro Surveill 2013;18(13):1-9.

2. Gushulak B, Weekers J, Macpherson D. Migrants and emerging public health issues in a globalized world: threats, risks and challenges, an evidence-based framework. Emerg Health Threats J 2009;2:e10.

3. Pybus OG, Tatem AJ, Lemey P. Virus evolution and transmission in an ever more connected world. Proc Biol Sci 2015;282(1821):20142878.

4. Lindahl J, Grace D. The consequences of human actions on risks for infectious diseases: a review. Infect Ecol Epidemiol 2015;5:30048.

5. Henderson DA. The looming threat of bioterrorism. Science 1999;283(5406):1279-1282.

6. Lloyd's. Chatham House. The Royal Institute of International Affairs. Use of Chemical, Biological, Radiological and Nuclear Weapons by Non-State Actors Emerging Trends and Risk Factors. Emerging Risk Reports. 2016. file://C:/Users/ jacfox/Downloads/CBRN.pdf. Accessed June 26, 2017.

7. Science and Technology Organization. STO Technical Report State-of-the-Art in Research on Medical Countermeasures against Biological Agents. Vol. STO-TR-HFM-186. 2016.

8. Magnuson M, Ernst H, Griggs J, et al. Analysis of environmental contamination resulting from catastrophic incidents: Part 1 . Building and sustaining capacity in laboratory networks. Environ Int 2014;72:83-89.

9. Morse SA, Kellogg RB, Perry S, et al. Detecting biothreat agents: the Laboratory Response Network. ASM News 2003; 69(9):433-437.

10. Defence Research and Development Canada. Chemical, Biological, Radiological-nuclear and Explosives Research and Technology Initiative. Annual report. 2012;D66-1E-PDF.

11. Hwang HS. The strategic plan for preparedness and response to bioterrorism in Korea. J Prev Med Public Health 2008; 41(4):209-213.

12. National Institute for Public Health and the Environment RIVM. Landelijk Laboratorium Netwerk terreur aanslagen. http://www.rivm.nl/Onderwerpen/O/Ongevallen_en_rampen/ Terrorisme. Accessed June 29, 2016.

13. Mèrens A, Cavallo JD, Thibault F, et al. Assessment of the bio-preparedness and of the training of the French hospital laboratories in the event of biological threat. Euro Surveill 2012;17(45):pii $=20312$.

14. Roffey R, Lantorp K, Tegnell A, Elgh F. Biological weapons and bioterrorism preparedness: importance of public-health awareness and international cooperation. Clin Microbiol Infect 2002;8(8):522-528.
15. Commission of the European Communities. Green Paper on bio-preparedness. COM (2007) 399. 2007. Brussels: http://ec. europa.eu/transparency/regdoc/rep/1/2007/EN/1-2007-399EN-F1-1.Pdf. Accessed June 27, 2017.

16. Sirbu M. Green Paper on bio-preparedness-general comments. J Med Life 2007;3(4):430-432.

17. Council of the European Union. Council conclusions on strengthening chemical, biological, radiological and nuclear (CBRN) security in the European Union-an EU CBRN Action Plan-Adoption. Brussels; 2009. 15505/1/09(REV1).

18. The European Parliament and the Council of the European Union. Legislative act on serious cross-border threats to health. Off J Eur Union 2013;L 293/1(Decision No 1082/ 2013/EU).

19. World Health Organization. International Health Regulations (2005). 2d ed. http://www.who.int/topics/international_ health_regulations/en/. Accessed June 27, 2017.

20. Sundqvist B, Bengtsson UA, Wisselink HJ, et al. Harmonization of European laboratory response networks by implementing CWA 15793: use of a gap analysis and an "insider" exercise as tools. Biosecur Bioterror 2013;11 (Suppl 1):S36-S44.

21. EMERGE. Efficient response to highly dangerous and emerging pathogens at EU level. http://www.emerge.rki.eu/. Accessed June 27, 2017.

22. Bergling P, Engberg J, Naarttijärvi M, Wennerström E, Wimelius ME. Krisen, myndigheterna och lagen: Krishantering i rättens gränsland. [The crisis, the agencies and the law: crisis management in the grey zone of justice]. $2015 \mathrm{ed}$. Malmö: Gleerups Utbildning AB; 2015. Swedish.

23. Regeringens proposition 2007/08:92. Stärkt krisberedskapför säkerhets skull. [Proposition from the government. Strengthened crisis preparedness-for the sake of safety]. 2007. Swedish.

24. Hedman J, Knutsson R, Ansell R, Rådström P, Rasmusson B. Pre-PCR processing in bioterrorism preparedness: improved diagnostic capabilities for laboratory response networks. Biosecur Bioterror 2013;11(Suppl 1):S87-S101.

25. Burnett JC, Henchal EA, Schmaljohn AL, Bavari S. The evolving field of biodefence: therapeutic developments and diagnostics. Nat Rev Drug Discov 2005;4(4):281-297.

26. Åkerlind B. Beredskapssamordning av mikrobiologiska laboratoriefunktioner hos myndigheter och sjukvårdshuvudmän [Coordination of microbiological laboratory functions at government agencies and the health care sector]. Rep to Swedish Natl Board Heal Welf. Stockholm; 2006.

27. Knutsson R, Frosth S, Ehrs S, et al. Hot- och risker i livsmedelskedjan: Resurslaboratorium för beredskapsdiagnostik. [Threats and risks in the alimentary chain: resource laboratory for preparedness diagnostics]. Livsmedel i Fokus 2009;1(47). Swedish.

28. Swedish Civil Contingencies Agency. MSB Publication search. https:/www.msb.se/en/Products/Publications/Publicationsearch/. Swedish.

29. Westerdahl K. Utvärdering 2015 av anslag 2:4 Krisberedskap : nyttan av nätverk. [Inventory 2015 of Crisis Preparedness grants 2:4: the benefit of networks]. Swedish Civ Contingencies Agency, MSB. 2016;MSB938. Swedish.

30. Centers for Disease Control and Prevention. Facts about the Laboratory Response Network. http://emergency.cdc.gov/ lrn/factsheet.asp. Accessed June 27, 2017. 
THELAUS ET AL

31. Marshall S, Brokopp CD, Size T. Leadership principles for developing a statewise public health and clinical laboratory system. Public Health Rep 2010;125(2):110-117.

32. Lewerin SS, Elvander M, Westermark T, et al. Anthrax outbreak in a Swedish beef cattle herd-1st case in 27 years: case report. Acta Vet Scand 2010;52(1):7.

33. Kaden R, Ågren J, Båverud V, et al. Brucellosis outbreak in a Swedish kennel in 2013: determination of genetic markers for source tracing. Vet Microbiol 2014;174(3):523-530.

34. Lagerqvist N, Hagström $\AA$, Lundahl M, et al. Molecular diagnosis of Puumala virus-caused hemorrhagic fever with renal syndrome. J Clin Microbiol 2016;54(5):1335-1339.

35. Lindquist HDA, Harris $S$, Lucas $S$, et al. Using ultrafiltration to concentrate and detect Bacillus anthracis, Bacillus atrophaeus subspecies globigii, and Cryptosporidium parvum in 100-liter water samples. J Microbiol Meth 2007;70(3):484-492.

36. Donoso Mantke O, Schmitz H, Zeller H, et al. Quality assurance for the diagnostics of viral diseases to enhance the emergency preparedness in Europe. Euro Surveill 2005;10(6):102-106.

37. Knutsson R, van Rotterdam B, Fach P, et al. Accidental and deliberate microbiological contamination in the feed and food chains-How biotraceability may improve the response to bioterrorism. Int J Food Microbiol 2011;145(Suppl 1):S123-S128.

38. Institute of Medicine (US). Forum on Microbial Threats. Global Infectious Disease Surveillance and Detection: Assessing the Challenges_Finding Solutions. Workshop Summary. Washington, DC: National Academies Press; 2007.

39. European Committee for Standardization CEN. CWA 15793:2008 Laboratory biorisk management. CWA. Brussels; 2008.

40. ISO. International Standard ISO/IEC 17025 General requirements for the competence of testing and calibration laboratories. International Standard; 2005.
41. Adams LG. Putting together a scientific team: collaborative science. Trends Microbiol 2014;22(9):483-485.

42. Gronvall G, Boddie C, Knutsson R, Colby M. One Health security: an important component of the global health security agenda. Biosecur Bioterror 2014;12(5):221-224.

43. Pennisi E. Pocket DNA sequencers make real-time diagnostics a reality. Science 2016;351(6275):800-801.

44. Park KS, Huang C-H, Lee K, et al. Rapid identification of health care-associated infections with an integrated fluorescence anisotropy system. Sci Adv 2016;2(5):e1600300.

45. Atlas RM. One Health: its origins and future. Curr Top Microbiol Immunol 2013;365:1-13.

46. The World Bank. People, pathogens and our planet. Volume 2. The Economics of One Health. Washington DC: World Bank; 2012.

47. Christodoulou M, Caspari C, Garrone M, et al. Evaluation of the EU rapid response network, crisis management and communication capacity regarding certain transmissible animal diseases. Final Report. DG SANCO Eval Framew Contract Lot 3 Food Chain. Brussels; 2012.

Manuscript received November 8, 2016;

revision received January 31, 2017;

accepted for publication February 22, 2017.

Address correspondence to: Johanna Thelaus, PhD Researcher Division of CBRN Defence and Security Swedish Defence Research Agency SE- 90182 Umea, Sweden

Email: johanna.thelaus@foi.se 